\title{
ABOVE-GROUND TUBER FORMATION OF POTATOES
}

\author{
G. A. THIJN \\ Foundation of Agricultural Plant Breeding, Wageningen \\ With 4 figures \\ Received 22 Jan. 1959
}

\begin{abstract}
Potato plants will produce tubers under any condition of growth. If normal tuber formation under ground is prevented, then the formation of tubers or tuberous swellings is effected by accumulation of assimilates in above-ground portions of the stem.
\end{abstract}

\section{INTRODUCTION}

When a potato tuber is planted the resulting plant will produce tubers only by enlarging the extremities of its stolons, provided that no particular growth disturbances occur. These stolons are underground offshoots of the stem. Any portion of the stem, including the tubers themselves, can also produce adventitious roots under the ground.

Stolons are often formed at the nodes low on the stem portions of potatoes grafted on tomato rootstocks. These stolons grow downwards, but do not develop tubers before they have penetrated into the soil. Apparently stolons can only produce tubers. under ground.

Under abnormal conditions stem portions other than the extremities of stolons can also enlarge to tubers. In the fields it is observed regularly that buds in the axils of the lowermost leaves grow into tubers, as a result of an attack by Rhizoctonia solani KüHN or by injury of the stem during cultivation.

Particularly after applying flower inducing procedures, such as grafting potato shoots on tomato rootstocks or raising potato plants on stones, tuber formation can be observed in the leaf axils and even in the flower trusses, especially towards the end of the growing season (THIJN, 1).

When root formation is disturbed, cuttings of potato stems sometimes produce small tubers on the stem portion that is covered by the soil.

In all these cases tuber formation takes place by accumulation of assimilates in axil buds of ordinary or transformed leaves.

However, tubers have never been observed to form on roots. Apparently the roots. also lack the capacity to produce stolons. If a potato could be raised in such a way that only roots and no shoot tissue developed in the soil, it would be interesting to observe the tuber-forming behaviour of the above-ground parts of the plant would respond to this. Using a tuber or other portion of the stem as the starting point it would be difficult to prevent tuber formation. However, when potato seedlings are used it should be feasible to raise plants that have only a root system of main and adventitious roots and no stem tissue in the soil. 


\section{EXPERIMENTS}

Potato seeds were sown in fertile soil in March. By putting the seed tray in the dark before emergence, seedlings were obtained with cotyledons which rose some $2 \mathrm{~cm}$ above the ground. As soon as these seedlings started growing - which could be ascertained from the elongation of the main stem - they were carefully transplanted into pots of $10 \mathrm{~cm} ø$, taking care that they were not pricked out deeper than they had stood in the seed tray (consequently so deep that the cotyledons rose some $2 \mathrm{~cm}$ above the ground). Later when the experiment was repeated, the seed was sown directly into the pots so that transplanting was avoided. The position of the plants was such, therefore, that the hypocotyle axis, that is the portion under the cotyledons, entirely or for the greater part rose above the soil.

\section{ObSERVATIONS}

About 10 days after pricking them out, the plants began to show abnormal behaviour, some sooner than others. They developed stolons growing downwards from the axils of the cotyledons, thus at the lowermost stem nodes. These stolons were removed.

Some time later most of the plants produced stolons at upper stem nodes and sometimes even at those of the lateral shoots. These also were removed. If this had not been done then the downwards growing stolons would have produced tubers as soon as they had penetrated into the soil and this had to be prevented.

Sixteen of the original 17 seedlings also showed other aberrations. Some aboveground portions of the stem enlarged and each seedling did so in its own peculiar way.

Most of them formed tuberous swellings in the hypocotyle axis, which sometimes later produced roots. Others formed heavily swollen internodes or nodes (fig. 1) and again others developed tubers by enlarging the extremities of the lateral shoots (fig. 3) or in the axils of the leaves. Some of these tubers which had each a colour peculiar for each plant, produced lateral tubers and often formed small leaves (fig. 2). In many cases combinations of the above-mentioned swellings occurred on the one plant (fig. 4).

All the seedlings but one very clearly showed accumulation of assimilates in some portion of the stem and finally 16 plants adopted an entirely aberrant and very unusual habit. The tubers, swollen portions of the stem, apparently had not been produced in the ground, but above-ground. This became evident when the underground parts of the plants were examined in June after they total had died. The 16 aberrant plants had developed a very extensive root system, originating from the main root, but there was no tuber formation in the soil. However, the one plant which had shown no aboveground aberrations had produced a fairly large tuber at a stolon that unobservedly had grown into the soil from the lowermost node.

\section{Discussion OF THE RESUlts}

From the experiments it is clear that a potato plant during its growth will produce tubers or tuberous swellings on stem portions, be it sooner or later. Normally these accumulations of assimilates are developed in special underground organs, but under particular conditions these swellings can also be produced at above-ground stem portions or even only there. 


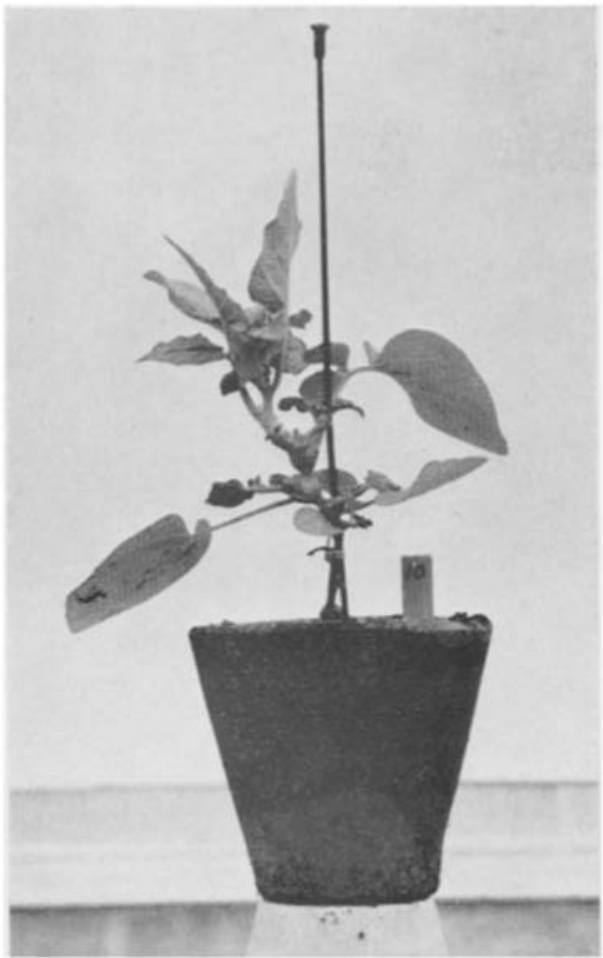

Fig. 1. SEEDLING With SWOLlen INTERNODES AND NODES

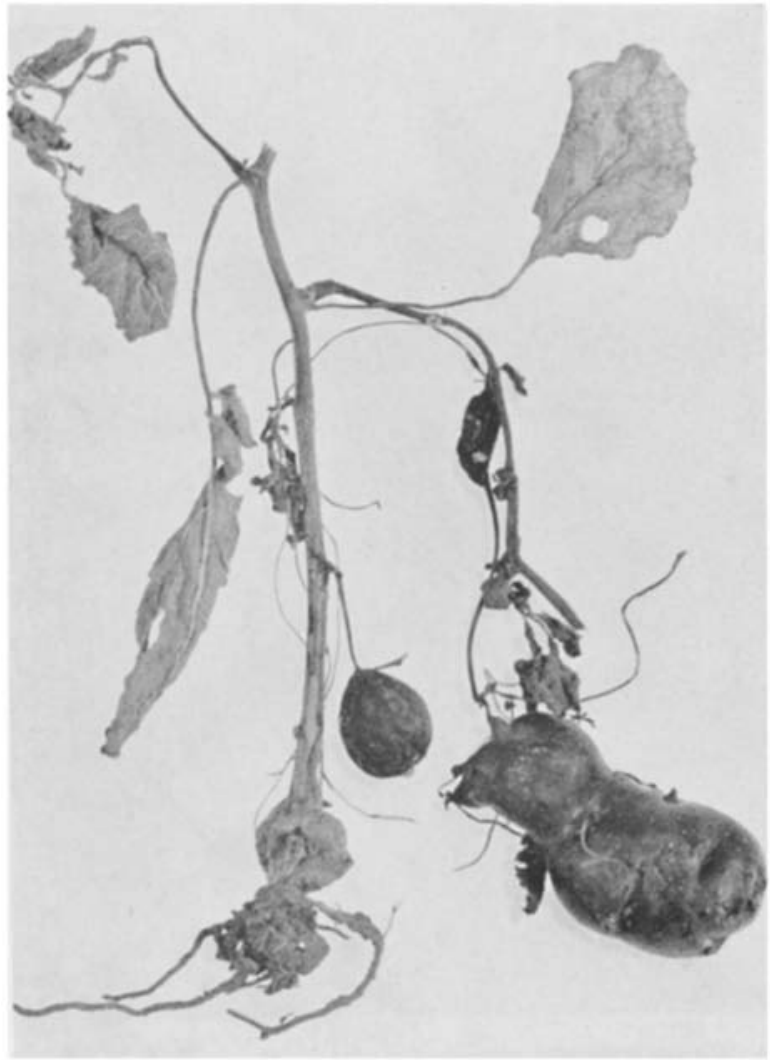

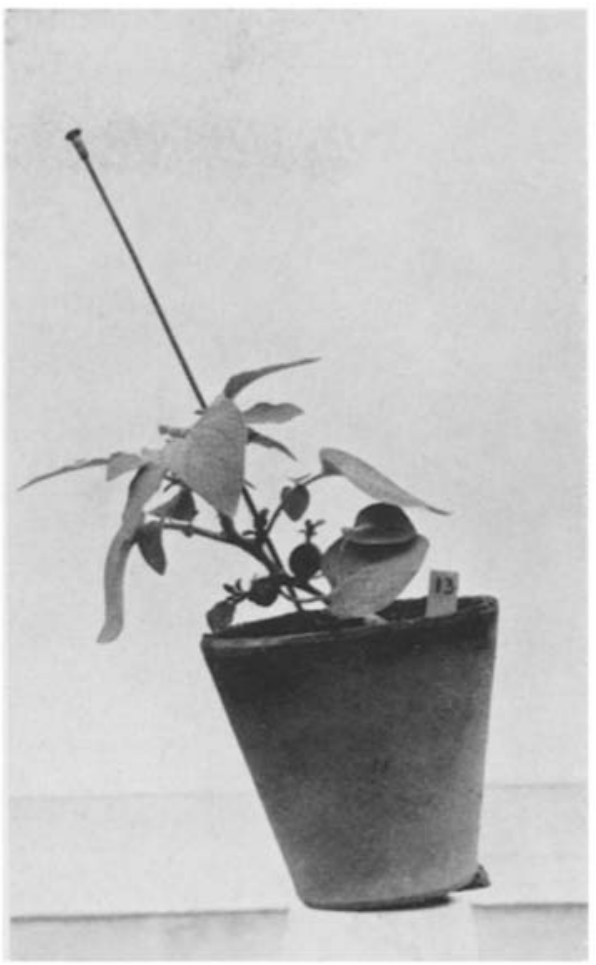

Fig. 2. Seedling with tubers in the axils or THE LEAVES; ON THE TUBERS SMALL LEAVES ARE FORMED

Fig. 3. Seedling with swellings OF THE STEM BASIS AND OF THE EXTREMITY OF A LATERAL SHOOT 
G. A. THIJN

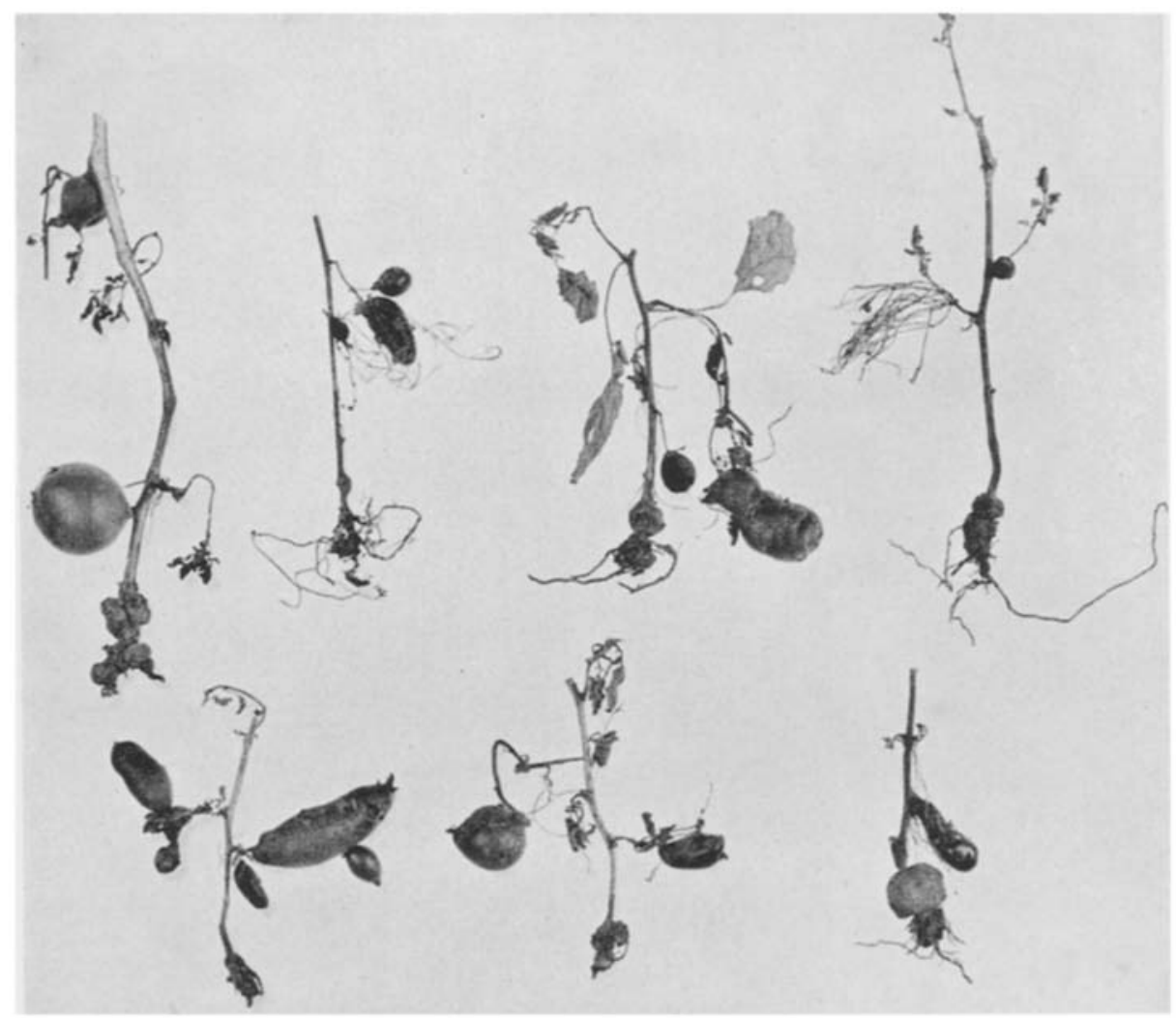

Fig. 4. Seedlings With sWellings on different Parts of THE STEM 
The colour of the above-ground parts also varied widely in the experiment; this will be the result of its genetical constitution. The normal production of tubers on underground stolons is only one of the many possible ways of tuber formation of the potato and for the plant possibly the most rational one, because the tubers in which a quantity of assimilates has been accumulated are the reproductive organs of the plant, and the chance of continuance of the species is greatest when the tubers are developed underground. Only under very particular conditions a potato plant will form its reproductive organs above the ground.

It is to be expected that under normal conditions of growth normal plants can be produced from the above-ground tubers. This has proved to be so. From such tubers and also from cuttings of plants which produced such tubers, ordinary plants have been successfully raised.

\section{SAMENVATTING \\ Bovengrondse knolvorming bij aardappelen}

Een aardappelplant tracht steeds knollen te vormen. Wordt de normale wijze van knolvorming onder de grond verhinderd, dan vindt vorming van knollen of knolachtige verdikkingen plaats door ophoping van assimilaten in bovengrondse stengeldelen.

\section{REFERENCE}

1. ThIJ, G. A., Observations on flower induction with potatoes. Euphytica 3 (1954): 28-34. 